\title{
ASSESSMENT OF FOREST ECOSYSTEM HEALTH BASED ON FUZZY EVALUATION METHOD-A CASE STUDY OF FOREST ECOSYSTEM IN LIANGSHUI NATURAL RESERVE
}

\author{
Ning $\mathrm{TAO}^{1}$, Dan $\mathrm{LIU}^{1 *}$ and Jiang $\mathrm{WU}^{2}$ \\ ${ }^{1}$ College of Art, Northeast Agricultural University, Heilongjiang, Harbin 150000, China \\ ${ }^{2}$ Department of human and Engineered Environment Studies, The University of Tokyo, Chiba, Japan \\ *E-mail: 1442460795@qq.com.
}

(Received May 2018; accepted July 2018)

Key words: forest ecosystem, health assessment; analytic hierarchy process (AHP), fuzzy evaluation method

\begin{abstract}
Based on the establishment of health assessment index system of forest ecosystem in Liangshui Natural Reserve, the weight of each index was determined by using analytic hierarchy process (AHP) and questionnaire method, and then the model of forest ecosystem fuzzy evaluation was established to assess the health of Liangshui Natural Reserve from 2007 to 2013. The results indicated that certain changes have taken place to the health of forest ecosystem in Liangshui Natural Reserve from 2007 to 2013, which showed a declining trend, while the trend of the change is also consistent with the changes of internal and external environments of the forest ecosystem in Liangshui Natural Reserve.

Palabras clave: ecosistema forestal, determinación de salud, proceso analítico jerárquico, método de evaluación difusa

\section{RESUMEN}

Con base en el establecimiento del índice de salud del ecosistema forestal en la Reserva Natural Liangshui, el peso de cada índice se determinó por medio del proceso de análisis jerárquico y de un cuestionario y, posteriormente, se estableció el modelo de evaluación forestal difuso para determinar la salud de la Reserva Natural Liangshui de 2007 a 2013. Los resultados indican que hubo ciertos cambios en la salud del ecosistema forestal de la Reserva entre 2007 y 2013 , mostrando una tendencia a la declinación; los cambios fueron consistentes con los cambios internos y externos al sistema forestal de la Reserva Natural Liangshui.
\end{abstract}




\section{ESTABLISHMENT OF EVALUATION INDEX SYSTEM}

Health assessment index system of forest ecosystem is shown in Table I.

\section{DETERMINATION OF EVALUATION INDEX WEIGHT}

The index weight is used to quantify each index in the overall evaluation so as to show the different important levels and the reasonable factors that directly affect the scientificalness of final evaluation results(Li et al. 2007, Xiao et al. 1997, Zahan et al. 2018). At present, many methods determine the weight of index, including the analytic hierarchy process, expert scoring method, factor analysis, discriminant analysis, sequence synthesis method and principal component analysis method (Wang et al. 2008, Xiao and Ouyang 2004). Among all the aforementioned methods, the analytic hierarchy process (AHP) is widely used for determining index weight, which has also been proved to be an effective method in this regard(Wang et al. 2010, Zhao et al. 2008, Zhang et al. 2003, Lijie and Feng 2018). The quantification of empirical judgment from the decision maker is conducive to the accuracy, because such empirical judgments both practical and effective for dealing with the complex structure and insufficient statistical data. AHP method uses an orderly hierarchical index system to synthetically calculate the weight coefficient of the index by comparing the relative priority of each index at the same level. Specific steps are as follows:

(1) Form valuation matrix $Z$ by comparing the evaluation of every two indexes, and each element $\mathrm{a}_{\mathrm{ij}}$ in $\mathrm{Z}$ refers to the value of importance comparison between every two indexes of and i row and relative $\mathrm{j}$ column. Among judgment matrix $\mathrm{Z}, \mathrm{a}_{\mathrm{ij}}>0$, $a_{i j}=1 / a_{i j}$ (among which, $i, j=1,2, \ldots, n$ ). It can be seen that the judgment matrix $\mathrm{A}$ is an orthogonal matrix.

TABLE I. INDEX SYSTEM FOR HEALTH ASSESSMENT OF FOREST ECOSYSTEM.

\begin{tabular}{|c|c|c|c|}
\hline Primary index & $\begin{array}{l}\text { Primary index } \\
\text { code }\end{array}$ & Secondary index & Index code \\
\hline \multirow{4}{*}{$\begin{array}{l}\text { Landscape } \\
\text { Structure }\end{array}$} & \multirow{4}{*}{$\mathrm{X}_{1}$} & Vegetation Coverage & $\mathrm{X}_{11}$ \\
\hline & & Public Green Space Area Per Capita & $\mathrm{X}_{12}$ \\
\hline & & Landscape Fragmentation & $\mathrm{X}_{13}$ \\
\hline & & Landscape Corridor Density & $\mathrm{X}_{14}$ \\
\hline \multirow{4}{*}{$\begin{array}{l}\text { Ecological } \\
\text { Functions }\end{array}$} & \multirow{4}{*}{$\mathrm{X}_{2}$} & Removal of Atmospheric Pollutant & $\mathrm{X}_{21}$ \\
\hline & & Carbon Dioxide Absorption & $\mathrm{X}_{22}$ \\
\hline & & Released Oxygen & $\mathrm{X}_{25}$ \\
\hline & & Reducing dust & $\mathrm{X}_{26}$ \\
\hline \multirow{3}{*}{$\begin{array}{l}\text { Environment and } \\
\text { Management }\end{array}$} & \multirow{3}{*}{$\mathrm{X}_{3}$} & Comprehensive Air Pollution Index & $\mathrm{X}_{31}$ \\
\hline & & The Frequency of Acid Rain & $\mathrm{X}_{32}$ \\
\hline & & Incidence of Pests and Diseases & $\mathrm{X}_{33}$ \\
\hline \multirow{6}{*}{$\begin{array}{l}\text { Plant } \\
\text { Diversity }\end{array}$} & \multirow{6}{*}{$\mathrm{X}_{4}$} & Diversity of Tree Structure & $\mathrm{X}_{41}$ \\
\hline & & Evenness of Tree Structure & $\mathrm{X}_{42}$ \\
\hline & & Dominance of Tree Structure & $\mathrm{X}_{43}$ \\
\hline & & Diversity of Planting Structure & $\mathrm{X}_{44}$ \\
\hline & & Evenness of Planting Structure & $\mathrm{X}_{45}$ \\
\hline & & Dominance of Planting Structure & $\mathrm{X}_{46}$ \\
\hline
\end{tabular}


(2) The product of each row in judgment matrix mi $=\Pi_{j=1}^{n} a_{i j}, i=1,2,3, \cdots, n$

(3) Calculate the $\mathrm{n}$-th root $\overline{\mathrm{W}}_{1}$ of $\mathrm{m}_{\mathrm{i}}$,

(4) Carry out the vector $\mathrm{w}=\left[\overline{\mathrm{w}_{1}}, \overline{\mathrm{w}_{2}}, \ldots, \overline{\mathrm{W}_{\mathrm{n}}}\right]^{\mathrm{T}}$ with normalization processing to get the corresponding weight $\mathrm{w}_{\mathrm{i}}$ of each index:

$w_{i}=\overline{w_{l}} / \sum_{1}^{n} \overline{w_{l}}$

For the purpose of this paper, the corresponding questionnaire was designed based on the specific index, and a survey was conducted among 89 experts and researchers engaged in forest system evaluation. The CR value of the consistency test questionnaire was 0.004 . Such a value meets the requirement of the consistency test. The normalized index weight is shown in Table II.

TABLE II. NORMALIZED INDEX WEIGHT OF FOREST ECOSYSTEM.

\begin{tabular}{cccc}
\hline $\begin{array}{c}\text { Index } \\
\text { Code }\end{array}$ & $\begin{array}{c}\text { Weight } \\
\text { (Normalization) }\end{array}$ & $\begin{array}{c}\text { Index } \\
\text { Code }\end{array}$ & $\begin{array}{c}\text { Weight } \\
\text { (Normalization) }\end{array}$ \\
\hline $\mathrm{X}_{11}$ & 0.054278593 & $\mathrm{X}_{26}$ & 0.047909166 \\
$\mathrm{X}_{12}$ & 0.041816671 & $\mathrm{X}_{31}$ & 0.042924398 \\
$\mathrm{X}_{13}$ & 0.042370534 & $\mathrm{X}_{32}$ & 0.039601218 \\
$\mathrm{X}_{14}$ & 0.056770978 & $\mathrm{X}_{33}$ & 0.055663251 \\
$\mathrm{X}_{21}$ & 0.029631681 & $\mathrm{X}_{41}$ & 0.079756300 \\
$\mathrm{X}_{22}$ & 0.044862919 & $\mathrm{X}_{42}$ & 0.034339518 \\
$\mathrm{X}_{23}$ & 0.060924952 & $\mathrm{X}_{43}$ & 0.039324287 \\
$\mathrm{X}_{24}$ & 0.075602326 & $\mathrm{X}_{44}$ & 0.052340072 \\
$\mathrm{X}_{25}$ & 0.042093603 & $\mathrm{X}_{45}$ & 0.034616450 \\
& & $\mathrm{X}_{46}$ & 0.037939629 \\
\hline
\end{tabular}

\section{ESTABLISHMENT OF FUZZY COMPREHENSIVE EVALUATION MODEL}

The health of the ecosystem is evaluated in a relative manner. Each index of the ecosystem is evaluated according to the existing standards, and then all indexes evaluation results from the overall evaluation (Lu et al. 2005, Ma et al. 2001, Yuan et al. 2012, Nawaz et al. 2018). The basic idea of the fuzzy mathematics method is to use the fuzzy relationship synthetic principle to characterize and describe components key for quantity according to the state or the property of evaluation object itself (Ali et al. 2017). In this paper, the fuzzy mathematics evaluation method is applied to evaluate the forest ecosystem health. This is the reason why this paper chooses the following fuzzy mathematics evaluation model.
The first step is to determine the membership value of each index. If any element $\mathrm{x}$ in discourse domain $\mathrm{U}$ has a corresponding number, $\mathrm{A}(\mathrm{x}) \in[0,1]$, it is said that $\mathrm{A}$ is the fuzzy set on $\mathrm{U}$ and $\mathrm{A}(\mathrm{x})$ is said thatrefers to the membership of $X$ to $A$. In this paper, the classic triangular fuzzy function was used to quantify the membership value of each index in each valuation level, as the position $\mathrm{T}_{1}$ in Fig. 1, the membership value $A_{n}^{m}$ is as follows:

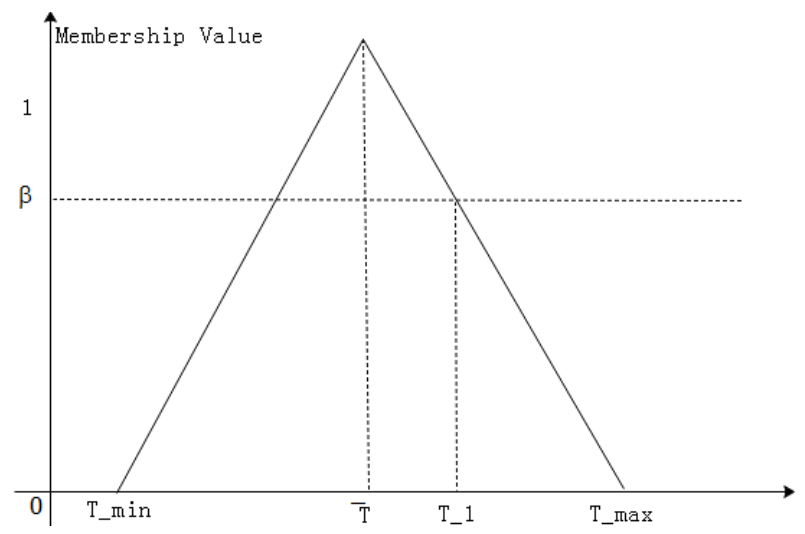

Fig. 1.Transformation Diagram of Membership

$$
A_{n}^{m}=\left\{\begin{array}{lc}
0, & T_{1}<T_{\min } \\
f_{1}(t), & T_{\min } \leq T_{1}<\bar{T} \\
a_{1}, & T_{1}<\bar{T} \\
g_{1}(t), & \bar{T}<T_{1}<T_{\max } \\
0, & T_{\max } \leq T_{1}
\end{array}\right.
$$

Based on the aforementioned formula, $m$ indicates the m-th index, $\mathrm{n}$, level $\mathrm{n}$, and $A_{n}^{m}$ indicates, the membership value of $m$-th index in $n$-th level. At the same time, the expressions of $f_{1}(t)$ and $g_{1}(t)$ in the above are respectively as follows:

$$
\begin{aligned}
& f_{1}(t)=\frac{T_{1}-T_{\text {min }}}{\bar{T}-T_{\text {min }}} \\
& g_{1}(t)=\frac{T_{\text {max }}-T_{1}}{T_{\text {max }}-\bar{T}}
\end{aligned}
$$

So, A refers tothe membership matrix in the case of $\mathrm{m}$-th index and $\mathrm{n}$-th level:

$$
A=\begin{array}{cccc}
A_{1}^{1} & A_{1}^{2} & \cdots & A_{1}^{m} \\
A_{2}^{1} & A_{2}^{2} & \cdots & A_{2}^{m} \\
\vdots & \vdots & \vdots & \vdots \\
A_{n}^{1} & A_{n}^{2} & \cdots & A_{n}^{m}
\end{array}
$$


The problem studied in this paper includes 21 indexes and 5 evaluation levels, so $\mathrm{m}$ and $\mathrm{n}$ in the formula are respectively as 21 and 5 .

Therefore, the fuzzy evaluation model of forest ecosystem can be obtained as follows:

Results $=\mathrm{W}^{\mathrm{o}} \mathrm{A}\left(\mathrm{W}_{1}, \mathrm{~W}_{2}, \cdots, \mathrm{W}_{\mathrm{m}}\right)^{\mathbf{o}}\left|\begin{array}{cccc}A_{1}^{1} & A_{1}^{2} & \cdots & A_{1}^{m} \\ A_{2}^{1} & A_{2}^{2} & \cdots & A_{2}^{m} \\ \vdots & \vdots & \vdots & \vdots \\ A_{n}^{1} & A_{n}^{2} & \cdots & A_{n}^{m}\end{array}\right|$

Based on the above formula, W indicates the weight matrix of each index:

$\mathrm{W}=\left(\mathrm{W}_{1}, \mathrm{~W}_{2}, \cdots, \mathrm{W}_{\mathrm{m}}\right)$

\section{EMPIRICAL ANALYSIS BASED ON FOREST ECOSYSTEM OF LIANGSHAN NATURAL RESERVE}

Liangshui Natural Reserve is located in the southeast of Xiao HingganLing Mountains with the reserve area of 12,133 square $\mathrm{hm}$. It is $13.0 \mathrm{~km}$ in width from east to west and $17.0 \mathrm{~km}$ in length from north to south. The northernmost altitude is 707.3 $\mathrm{m}$, which gradually decreases to $300 \mathrm{~m}$ to the south. The relative height of mountains is $100-200 \mathrm{~m}$ above the sea level. The whole area is mountainous with more complex terrain. The main river in this district is Liangshui River. The reserve is affected by a temperate continental monsoon climate, so that the winter is long and the summer is short. The forest vegetation are covered in two types of landforms, respectively, mountain and valley. The forest coverage reaches $91.3 \%$. The reserve is served as the Chinese original coniferous and broad-leaved pinuskoraens is mixed forest and the biodiversity base, and the natural geography and ecological type of Liangshui Natural Reserve are typical in Xiao Hinggan Mountains, which belongs to the vertical zonal ecological environment type (Razali and Said 2017). For the purpose of the paper, data from 2007 to 2013 for the forest ecosystem in Liangshui Natural Reserve were collected based on the empirical experiment. The detail is shown in Table III.

According to the formula of evaluation model: , the membership matrix is calculated first, and then the the corresponding index weight is isused. Finally, the calculation result is obtained. The calculation is shown as follows:

$$
\begin{gathered}
\text { Results }=W * A\left(W_{1}, W_{2}, \cdots, W_{\mathrm{m}}\right) *\left|\begin{array}{cccc}
A_{1}^{1} & A_{1}^{2} & \cdots & A_{1}^{m} \\
A_{2}^{1} & A_{2}^{2} & \cdots & A_{2}^{m} \\
\vdots & \vdots & \vdots & \vdots \\
A_{n}^{1} & A_{n}^{2} & \cdots & A_{n}^{m}
\end{array}\right| \\
=(0.683,0.657,0.646,0.612,0.603,0.520,0.503)
\end{gathered}
$$

TABLE III. INDEX DATA ONFOREST ECOSYSTEM IN LIANGSHUI NATURAL RESERVE FROM 2007 TO

\begin{tabular}{|c|c|c|c|c|c|c|c|}
\hline Index Code & 2007 & 2008 & 2009 & 2010 & 2011 & 2012 & 2013 \\
\hline $\mathrm{X}_{11}$ & 0.32 & 0.32 & 0.31 & 0.31 & 0.26 & 0.22 & 0.22 \\
\hline $\mathrm{X}_{12}$ & 0.01 & 0.01 & 0.01 & 0.01 & 0.01 & 0.01 & 0.01 \\
\hline $\mathrm{X}_{13}$ & 0.32 & 0.64 & 0.55 & 0.63 & 0.59 & 0.65 & 0.63 \\
\hline $\mathrm{X}_{14}$ & 2.18 & 2.21 & 2.23 & 2.23 & 2.36 & 2.39 & 2.44 \\
\hline $\mathrm{X}_{21}$ & 60.92 & 59.70 & 58.50 & 58.50 & 49.73 & 42.27 & 42.27 \\
\hline $\mathrm{X}_{22}$ & 2474.90 & 2425.40 & 2376.89 & 2376.89 & 1602.25 & 1361.91 & 1270.66 \\
\hline $\mathrm{X}_{23}$ & 24.29 & 22.51 & 20.60 & 18.85 & 15.60 & 11.74 & 8.84 \\
\hline $\mathrm{X}_{24}$ & 61.11 & 65.22 & 61.05 & 56.98 & 50.09 & 52.21 & 48.24 \\
\hline $\mathrm{X}_{25}$ & 1252.76 & 1337.01 & 1251.53 & 1168.09 & 1026.85 & 1070.31 & 988.92 \\
\hline $\mathrm{X}_{26}$ & 1881.90 & 2088.91 & 2130.69 & 2343.76 & 2859.38 & 3113.87 & 3116.98 \\
\hline $\mathrm{X}_{31}$ & 2.79 & 2.63 & 2.84 & 2.90 & 2.91 & 23.11 & 3.25 \\
\hline $\mathrm{X}_{32}$ & 0.80 & 0.81 & 0.81 & 0.82 & 0.83 & 0.83 & 0.84 \\
\hline $\mathrm{X}_{33}$ & 0.02 & 0.02 & 0.02 & 0.02 & 0.02 & 0.02 & 0.02 \\
\hline $\mathrm{X}_{41}$ & 1.26 & 1.14 & 1.02 & 0.92 & 0.83 & 0.75 & 0.67 \\
\hline $\mathrm{X}_{42}$ & 0.62 & 0.60 & 0.58 & 0.44 & 0.41 & 0.36 & 0.32 \\
\hline $\mathrm{X}_{43}$ & 1.29 & 1.20 & 1.12 & 1.05 & 0.98 & 0.91 & 0.85 \\
\hline $\mathrm{X}_{44}$ & 1.23 & 1.25 & 1.27 & 1.26 & 1.19 & 1.20 & 1.30 \\
\hline $\mathrm{X}_{45}$ & 0.58 & 0.53 & 0.42 & 0.46 & 0.50 & 0.40 & 0.38 \\
\hline $\mathrm{X}_{46}$ & 0.71 & 0.70 & 0.62 & 0.55 & 0.43 & 0.34 & 0.27 \\
\hline
\end{tabular}
2013 
TABLE IV. EVALUATION ON FOREST ECOSYSTEM HEALTH

\begin{tabular}{lccccc}
\hline Classes & Unhealthy & Sub healthy & Healthy & Good Health & Best Health \\
\hline Health Score & $0-0.4$ & $0.5-0.55$ & $0.55-0.7$ & $0.7-0.85$ & $0.85-1$ \\
\hline
\end{tabular}

In order to facilitate quantitative comparison, this paper uses Tan Sanqing's standards for evaluating urban forest ecological health. The results have already been shown in Table IV (Tan and Zhang 2010, Xu et al. 2001, Ong et al. 2017, Ennaji et al. 2018).

According to the calculation results, it can be seen that from 2007 to 2013, the forest ecosystem in Liangshui Natural Reserve undergoes changes. Compared with the situation in 2007, 2013 witnesses the drop of health index by nearly $30 \%$. The current forest ecosystem in Liangshui Natural Reserve continues to decline. In recent years, the declining trend becomes even more obvious, which resulted in the changes. The ecosystem changes from health in 2007 to sub-health in 2013(Tiwari et al. 2017, $\mathrm{Fu}$ and Liu 2017, Li et al. 2018, Arshadullah et al. 2018). According to the present situation of forest ecosystem in Liangshui Natural Reserve, the scale of forest ecological tourism in Liangshui Natural Reserve is in direct proportion with the rapid development of tourism and the promotion of ecotourism in Liangshan Natural Reserve by the local government (Chybicki et al. 2016, Nolan et al. 2016, Guerrini et al. 2018, Kumruzzaman and Sarkar, 2017). Moreover, the development and construction of the surrounding areas are harmful to the water quality and air quality of forest ecosystem in reserve. As a matter of fact, the sustainability of the ecosystem has been damaged. It can be said that continuous attention should be paid to the future health of Liangshui Natural Reserve(Halim and Phang 2017).

\section{CONCLUSION}

In this paper, based on the characteristics analysis of forest ecosystem in Liangshui Natural Reserve, the index system for the health evaluation of forest ecosystem in Liangshui Natural Reserve was established and the weight of each index was determined through the questionnaire and AHP. Furthermore, fuzzy mathematics method is used for building the fuzzy health evaluation model of forest ecosystem Liangshui Natural Reserve. The empirical data, which can provide reference for the research of the forest ecosystem evaluation method, lays the foundation to evaluating the health of forest ecosystem in Liangshui Natural Reserve. Although many quantitative methods are used in this paper to carry out the evaluation, the complicated structure of forest ecosystem poses the high requirement to the involved evaluation indexes of its health assessment. Therefore, the future researches can be based on improving the index system for the health evaluation on forest ecosystem.

\section{ACKNOWLEDGMENTS}

This research was supported by The Art Science Planning Fund Forest Project of Heilongjiang Province in 2018, project number 2018B089

\section{REFERENCES}

Ali S.S., Ijaz N., Aman N., Nasir A., Anjum L. and Randhawa I.A. (2017). Clinical waste management practices in district faisalabad. Earth Sciences Pakistan. 1(2), 01-03.

Arshadullah M., Suhaib M., Baber R., Usama M., Zaman B., Mahmood I.A., Hyder S.I. (2017). Growth of chenopodiumquionawild under naturally salt affected soils. Malaysian Journal of Sustainable Agriculture. 1(1), 01-03.

Chybicki A., Kulawiak M., and Lubniewski Z. (2016). Characterizing surface and air temperature in the baltic sea coastal area using remote sensing techniques and gis. Polish Maritime Research. 23 (1), 3-11.

Ennaji W., Barakat A., Karaoui I., Baghdadi M.E., and Arioua A. (2018). Remote sensing approach to assess salt-affected soils in the north-east part of Tadla plain, Morocco. Geology, Ecology, and Landscapes. 2(1), 22-28.

Fu H., Liu X. (2017). A study on the impact of environmental education on individuals' behaviors concerning recycled water reuse. Eurasia Journal of Mathematics Science and Technology Education. 13 (10), 67156724.

Guerrini G., Landi E., Peiffer K., and Fortunato A. (2018). Dry grinding of gears for sustainable automotive transmission production. Journal of Cleaner Production. $176,76-88$. 
Halim N.I.A. and Phang I.C. (2017). Salicylic acid mitigates pb stress in nicotiana tabacum. Science Heritage Journal. 1(1), 16-19.

Kumruzzaman M. and Sarker A. (2017). Water requirements for various crops and impact of irrigation in barind area. Malaysian Journal of Sustainable Agriculture. 1(1), 04-07.

Li J.R., Zhang Z.M. and Luo K. (2007). Establishment of forest ecosystem health evaluation index system. Soil and Water Conservation Research, 14, 3, 173-175.

Li Z., Han C., and Gu T. (2018). Economics of biomass gasification: A review of the current status. Energy Sources Part B of Economics Planning \& Policy. 13 (2), 137-140.

Lijie L. and Feng Y. (2018). A Study on the rhythm and respiratory characteristics of Zhuang language. Acta Scientifica Malaysia. 2(1), 26-28.

Lu Q.X., He X.Y., and Wei Y.L. (2005). Study on health evaluation of urban forest ecosystem in Shenyang. Journal of Shenyang Agricultural Uinversity, 36 (5), 580-584.

Ma K.M., Kong H.M., and Guan W.B. (2001). Ecosystem health assessment: Methods and directions. Acta EcologicaSinica.

Nawaz A., Arshad F. and Khurshid F. (2018). Evaluation of low cost environment friendly natural extracts for the purification of drinking water. Acta Scientifica Malaysia. 2(1), 23-25.

Nolan C.B., Tufford D.L., and Chalcraft D.R. (2016). Needs assessment of coastal land managers for drought onset indicators in the southeastern united states. Journal of Coastal Research. 32 (5), 1016-1024.

Ong S.Q., Lee B.B., Tan G.P. and Maniam S. (2017). Capacity of black soldier fly and house fly larvae in treating the wasted rice in Malaysia. Malaysian Journal of Sustainable Agriculture. 1(1), 08-10.

Razali M.A.A. and Said F.M. (2017). Red pigment production by monascuspurpureus in stirred-drum bioreactor. Science Heritage Journal. 1(1), 13-15.

Tan S.Q., and Zhang G. (2010). Evaluation on urban forest health based on fuzzy comprehensive evaluation method: a case study onZhuzhou City in HunanProvince. Journal of Hunan Agricultural University (Edition of Natural Science), 36 (4), 474-477.
Tiwari V., Kumar M., and Trivedi S.P. (2017). Protective effects of perennial herb, Melissa officinalis against furadan $3 \mathrm{G}$ induced cytotoxicity in Channa punctatus. Journal of Environmental Biology, 38 (6), 1375-1381.

Wang Y.Q., Wu H. and Xu H.C. 2008. Health assessment on biodiversity and forest ecosystem for the butterflies in Zhejiang. Journal of Ecology, 28 (11), 5259-5269.

Wang Y.X., Lu Y.C., Zhang S.G. (2010). Status and prospect of forest ecosystem health assessment. Forestry Science, 46 (2), 134-140.

Xiao F.J., and Ouyang H. (2004). Forest ecosystem health assessment indicators and methods. Forest Resources Management, 1, 27-30.

Xiao F.J., Ouyang H., Fu B.J. and Niu, H. (1997). Assessment index for forest ecosystem health and its application in China. Journal of Geographical Sciences, 58 (6), 803-809, S. M. Hemmingsen, Soft Science. Saskatoon: University of Saskatchewan Press.

Xu F.L., Tao S., and Dawson R.W. (2001). Health assessment on lake ecosystem: indicators and methods. Water Research, 35 (13), 31-57.

Yuan F., Zhang X.Y., and Liang J. (2012). Developingindex system on health evaluation of forest ecosystem based on harmful interference. Journal of Ecology, 32 (3), 964-973.

Zahan T., Hashem A., Rahman M.M., Bell R.W. and Begum M. (2018). Efficacy of herbicides in non-puddled transplanted rice under conservation agriculture systems and their effectson establishment of the succeeding crops. Acta Scientifica Malaysia. 2(1), 17-25.

Zhang Q.G., Wang T.Y., and Zhong Q.L. (2003). Preliminary study on health assessment for forest ecosystem. Journal of Soil and Water Conservation, 17 (5), 16-18.

Zhao X.L., Zhou G.N., and Gao B.J. (2008). Application of principal component analysis in health assessment of forest ecosystem in Chengde County. Chinese Agricultural Science Bulletin, 24 (6), 400-403. 